\begin{tabular}{|c|c|}
\hline & $\begin{array}{l}\text { International Journal of Trend in Scientific } \\
\text { Research and Development (IJTSRD) }\end{array}$ \\
\hline 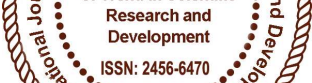 & International Open Access Journal \\
\hline 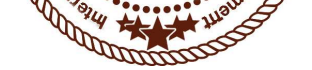 & ISSN No: 2456 - 6470 | www.ijtsrd.com | Volume - 2 | Issue - 2 \\
\hline
\end{tabular}

\title{
Exploring Stress related to Demographical factors and Confidence in Managing Stress with special reference to Female Faculties of Technical Education Institution in Dakshina Kananda District
}

\author{
Veena Shetty.S.S \\ Research Scholar, Department of MBA, \\ Srinivas Institute of Technology Valachil, \\ Mangalore, Karnataka
}

\author{
Dr. Surekha. I \\ Professor \& Head, Department of MBA, Kurunji \\ Venkataramana Gowda College of Engineering, \\ Dakshinakan, Sullia, Kannada, Karnataka
}

\section{ABSTRACT}

In higher education, teachers are experiencing pressures to increase productivity and efficiency at their work places to meet out the expectations of general public, management as well students which creates stress among them. In the field of engineering and technology, there is a significant gap in the study apprehension of teachers and this study aims to see the teachers apprehension and the self assurance they maintain to balance the work stress. Thus, the study sets out to investigate various causes of work stress among 615 engineering female faculty members of 15 engineering from different taluks of DakshinKannada district. The objectives of the study are to find out the significant difference and association among demographic variables of engineering female faculties on causes of stress. ' $t$ ' test and Chi-square test were used to analyse the data. The results showed a significant association among work family conflict, gender, working condition, work demand stress, career development technological challenges and gender issue causes of stress. The purpose of the paper is to identify the determinants.

Keywords: Stress, Work demand stress, Career development, Work family conflict, Gender issue

\section{INTRODUCTION}

Technical Education is a skilful, artful and a constructive education. It plays a vital role in human resource development of the country by creating skilled manpower, enhancing Industrial productivity and improving the quality of life. Faculties of Technical Educational Institution play an important role in shaping the behaviour of students and to develop their intelligence and attitude to deal with the unseen complexities of life and quality education especially in the beginning year. They are considered as a core stone of successful education system.

Teaching has often been attributed to be a physically wearing and psychologically stressful occupation (Sarah Basu, 2009). In higher education, pressure is mounting from the general public, management as well as from state and central government, to increase productivity and efficiency. This pressure will likely intensify the stress experienced by faculty. Stress in the workplace is generally considered to result when condition in the work environment are difficult for individual to manage. A survey at a research university, found that most faculty descried their job at least fairly stressful due to competing demands (Olsen and Maple, 1993). A teacher who is satisfied with his job can perform his duties efficiently and effectively and has a positive attitude towards teaching, but if he is under stress then he cannot work effectively and has a negative attitude towards his job. High stress can cause teachers to leave the profession. Stress is one of the many reasons teachers leave their jobs; unfortunately, many engineering colleges cannot find sufficient replacements and currently face several teacher shortages. Stress can lead to illness and 
absenteeism. When a qualified educator is absent from the classroom, student achievement is negatively affected (Woods and Montagno, 1997). Teacher stress is significantly correlated with the total number of days that teachers are away from college (Zoe and Denise, 1999). At present, the teacher is not satisfied with his job due to changing job conditions, insecurity of job, poor salary, biasness in promotions, work overload, role conflict, powerlessness, motiveless, harassment etc. (Geetha Nema et al. 2010).

\subsection{Need and Significance of The Study}

The study of stress management has assumed greater significance in the context of emerging trends of globalization and competitive environment. In India, both Central and State government have approved for high number of student's enrolment in engineering institutions in recent years. There is an increase in the awareness among people for the need of higher education, rising aspirations of the youth for better job opportunities and most of the parents desire a secured future for their children through better education. The expectations of the students and their parents are quiet high in private self-financing engineering colleges and colleges having the autonomy status. This in turn results in the demand for better performance from the faculties in private colleges as well. Keeping the competition in view the management demands good results from the faculty members and also their workload is much more than the faculty members of the other government colleges.

This Creates stress which leads to reduced faculty efficiency. Given the paucity of research that investigated the work stress in engineering education related to demographical variables, and confidence of faculties to deal with various type of stress related to work family conflict, work condition, work demand, work relation, career development, technological challenges and gender issue The findings of the study may be immensely useful for faculties, students Community and the public in general. It may hold benefit for institutions and faculties of engineering college. Stress is one of the many reasons faculties are leaving their jobs; unfortunately, many engineering colleges cannot find sufficient replacements and currently face several faculties' shortages. Although studies related to stress has been done with reference to faculties working in primary school, higher secondary school and arts colleges, self-sided colleges and deemed universities whereas only very few studies have been conducted in the areas of stress among female faculties of engineering colleges. Furthermore, the negative consequences of job stress on the work of college teachers induce further research on the stress among female engineering teachers in order to focus on, how to stem the tide of increasing stress among the faculties of higher educational institutions.

The present study has been carried out to identify the further reasons that are initially hidden to the previous researchers. In order to understand the consequences of stress and to be able to cope effectively, some of the major causes of stress should be identified.

1. How far demographical variable of engineering faculties differ significantly and associated with causes of stress?

2. How far demographical factor is significantly associated with the confidence in managing stress

Since faculties are one of the most important units in the educational system, it becomes essential to study the various aspects that influence them. or to reduce their intensity so as to increase the holding power of the profession. In the field of engineering and technology, there is a significant gap in the study of stress among the female teachers and this study aims to fill the gaps by examining the sources of work stress and the confidence to deal with the same. The study will identify the main stressors and the confidence to face the same. The study was limited to teaching female fraternity of engineering colleges only and the parameters for measuring the effects of stress were subjective rather than objective.

Thus, the study sets out to investigate various causes of work stress related to demographical variable and the confidence to deal with the same, among female faculty of 15engineering colleges coming under VTU affiliation in DakshinaKannada district and various coping strategies adopted by them to manage stress

\subsection{STATEMENT OF THE PROBLEM}

The study covers all factors that influence the Stress Management. Hence the present study is conceived under the title. "Technical Teachers Apprehensions and self-assurance with specific reference to Dakshin Kannada district"

\subsection{Implications of the Study}

The current study has provided an insight into the challenges faced by female faculty in engineering 
colleges in Dakshina Kannada district. Using this study, several other interesting factors that influence the self-assurance female faculty in engineering colleges can be identified. For instance, the impact of low job satisfaction and high stress levels on the job performance of faculties in engineering colleges in technical educational institution can be studied.

Studies conducted on female faculties in engineering faculty in India are limited. Therefore, similar studies can be conducted using a larger sample size. Conducting a study using a larger sample size would enhance the reliability of the data, which can further be used by the All India Council of Technical Education to enhance the quality of engineering education in India. If sample size is large, the results can also be generalized.

The current study is an attempt to understand technical teacher's apprehension and self-assurance and its impact on job performance. The data obtained from the study can be used to develop training, counselling and coaching model for faculty working in engineering colleges. Training the faculty to develop appropriate strategies to deal with stress and job dissatisfaction would help enhance the quality of teaching. Results provided in the current study can be used to conduct a comparative study with faculty belonging to other disciplines. This would help understand the challenges exclusively faced by engineering faculty. A comparative study will also help to know whether the factors effecting coping strategies employed by faculty vary with regard to the discipline they teach.

\section{Objectives}

A systematic study of stress among women faculties in engineering colleges in dakshinakannada district is very much needed the present study is conducted with the following objectives:

1. To identify the stress level based on various demographical variables

2. To ascertain the significant association between the stress level and the confidence in dealing with stress among female engineering teachers with demographic variables.

\section{Hypotheses}

H1: There is a significant relationship between Demographic factor and deal with different stress level

H2: There is a significant relationship between demographical factor and self efficacy in dealing stress

\section{Research Methodology}

\subsection{Data}

The data required for the study is primary in nature. The primary data are collected through making questionnaire. Pilot study was conducted with 50 faculty members who belong to engineering discipline. Based on the feedbacks and discussions with the academic experts, the questionnaire has been restructured.

\subsubsection{Period and area}

The study was conducted during the academic year 2016-17. Dakshin kannada district was chosen for the study because large number of engineering colleges are functioning in the district.

\subsubsection{Sample and tools employed}

Female faculties working in 15 engineering colleges who had experience of more than three years were selected for the study. Totally 716 questionnaires were distributed among the selected population using convenient sampling method. Only 615 questionnaires have been returned by the respondents. The collected data were analysed using's' test, and Chi-square test

\subsection{Limitations}

Data being primary in nature, all sorts of limitations applicable to primary data is applicable to the present study also. This study is confined to Coimbatore district so utmost care should be taken while generalizing the result. 
International Journal of Trend in Scientific Research and Development (IJTSRD) ISSN: 2456-6470

\section{Analysis and Interpretation}

Table No.4.1: Descriptive Statistic for Stress Scores

\begin{tabular}{|l|l|l|l|l|}
\hline $\begin{array}{l}\text { Descriptive statistics of stress scores } \\
\text { Stressors }\end{array}$ & Total & Mean & $\begin{array}{l}\text { Standard } \\
\text { Deviation }\end{array}$ & $\begin{array}{l}\text { Mean } \\
\text { Percentage }\end{array}$ \\
\hline $\begin{array}{l}\text { Individual Stressor /Work family conflict } \\
\text { stress }\end{array}$ & 45 & 20.57 & 7.313 & 45.71 \\
\hline Work Condition stress & 35 & 18.25 & 6.081 & 52.14 \\
\hline Work demand Stress & 50 & 24.45 & 8.368 & 48.90 \\
\hline Work relation Stress & 35 & 17.20 & 6.646 & 49.14 \\
\hline Career development & 25 & 12.81 & 4.862 & 51.24 \\
\hline Technological changes & 25 & 11.99 & 5.553 & 47.96 \\
\hline Gender Issues & 10 & 4.67 & 2.411 & 46.70 \\
\hline
\end{tabular}

Source: primary data

Table 4.1 shows the descriptive statistics for the stress level of the female faculties in Individual stressor and organization level stress,

Individual stressor /work family conflict consist of 9 components each having a maximum score of 5 , giving total maximum score of 45 , in which the mean is 20.57 with a standard deviation of 7.313 and mean percentage is 45.71 . On average, the respondents experienced moderate level of stress due to work/family conflict. Organizational levelestress consists work condition stress, work demand stress, work relation stress, stress on career development, technological changes and gender issue. Work condition stress consist of 7 components each having a maximum score of 5, giving total maximum score of 35 , in which the mean is 18.25 with a standard deviation of 6.081 , the mean percentage is 52.14 . Thus, the respondents experienced moderate level of stress due to work condition on average. Work demand stress consist of 10 components each having a maximum score of 5, giving total maximum score 50, in which the mean is 24.45 with a standard deviation of 8.368 , the mean percentage is 48.90 . Based on average work demand lead to a moderate level of stress in the respondents. Work relation Stress consist of 7 components each having a maximum score of 5 , giving total maximum score 35 , in which the mean is 17.20 with a standard deviation of 6.646 , the mean percentage is 49.14. On average, the respondents experienced moderate level of stress due to work relation. Career development stress consists of 5 components each having a maximum score of 5, giving total score 25 , in which the mean is 12.81 with a standard deviation of 4.862 , the mean percentage 51.24. The respondents experienced moderate level of stress due to Career development. Technology challenges Stress consist of 5 components each having a maximum score of 5 , giving total maximum score 25 , in which the mean is 11.19 with a standard deviation of 5.553 , the mean percentage is 47.96 . The mean stress due to Technology challenges is moderate, Gender Issue related Stress consist of 2 components each having a maximum score of 5 , giving total maximum score 10 , in which the mean is 4.67 with a standard deviation of 2.411 , the mean percentage 46.70 . On average, the respondents experienced moderate level of stress due to Gender issue.

Table No.4.2 Descriptive Statistic for Confidence Scores

\begin{tabular}{|l|l|l|l|l|}
\hline Lescriptive statistics of Confidence levels of Confidence & Total & Mean & $\begin{array}{l}\text { Standard } \\
\text { Deviation }\end{array}$ & $\begin{array}{l}\text { Mean } \\
\text { Percentage }\end{array}$ \\
\hline In balancing Work - family roles & 45 & 31.24 & 8.227 & 69.42 \\
\hline In facing Work Condition stress & 35 & 26.15 & 5.753 & 74.71 \\
\hline In meeting Work- demand & 50 & 37.74 & 9.049 & 75.48 \\
\hline In sustaining Work- relation & 35 & 26.30 & 6.628 & 75.14 \\
\hline In assuring Career development & 25 & 17.58 & 4.951 & 70.32 \\
\hline In responding to Technological changes & 25 & 18.90 & 5.561 & 75.60 \\
\hline In tackling Gender Issues & 10 & 7.31 & 2.604 & 73.10 \\
\hline
\end{tabular}


Source: primary data

Table 4.2 shows the descriptive statistics for the confidence level of the female faculties in dealing with Individual stressor and organization level stress. Individual stressor /work family conflict consist of 9 components each having a maximum score of 5, giving total maximum score of 45 , in which the mean is 31.24 with a standard deviation of 8.227 and mean percentage is 69.42. On average, the respondents experience moderate level of confidence in managing stress due to work/family conflict. Confidence in dealing with Organizational stress consists confidence level in work condition, work demand, work relation, career development, technological changes and gender issue. In Work condition confidence consist of 7 components each having a maximum score of 5 , giving total maximum score of 35 , in which the mean is 26.15 with a standard deviation of 5.753 , the mean percentage is 74.71. On average, the respondents experience high level of confidence in managing stress due to work condition.

Work demand confidence consist of 10 components each having a maximum score of 5, giving total maximum score 50, in which the mean is 37.74 with a standard deviation of 9.0498 , the mean percentage 75 . 48.. On average, the respondents experience moderate level of confidence in managing stress due to work demand. Work relation confidence consist of 7

Table. No 4.3:

Chi-square test results of association between Demographic factors and various stressors

Chi-square test results of association between Demographic factors and various stressors

\begin{tabular}{|c|c|c|c|c|c|c|c|}
\hline \multirow{3}{*}{$\begin{array}{l}\text { Demographic } \\
\text { s }\end{array}$} & \multicolumn{7}{|c|}{ 1OS/Various stressors } \\
\hline & $\begin{array}{l}\text { Work } \\
\text { family }\end{array}$ & $\begin{array}{l}\text { Work } \\
\text { conditi }\end{array}$ & Work & Working & $\begin{array}{l}\text { Career } \\
\text { development }\end{array}$ & $\begin{array}{l}\text { Technological } \\
\text { Challenges }\end{array}$ & $\begin{array}{l}\text { Gender } \\
\text { Issues }\end{array}$ \\
\hline & roles & & demand & relation & & & \\
\hline Age Group & $7.699 *$ & 7.001 & 3.648 & 4.917 & 2.525 & $10.634 *$ & $8.110^{*}$ \\
\hline $\begin{array}{l}\text { Marital Statu } \\
\text { s }\end{array}$ & $22.330 * *$ & .005 & 3.379 & 1.116 & .741 & $5.835^{*}$ & .162 \\
\hline $\begin{array}{l}\text { Spouse } \\
\text { employment }\end{array}$ & 2.769 & 1.435 & 4.549 & 1.267 & $14.576^{*}$ & .833 & 6.402 \\
\hline Family Type & $7.494 * *$ & .382 & $3.948 *$ & 3.069 & .367 & .012 & .002 \\
\hline
\end{tabular}

*Moderately Significant

**Highly Significant

Stress experienced due to Work family conflict varied significantly higher at the level of $(\mathrm{p}=0.00)$ in the variables Marital status $(\chi 2=22.330)$ and family type $(\chi 2=7.494)$. And moderately significant in age $\operatorname{group}(\chi 2=7.699)$. stress experienced due to Work components each having a maximum score of 5, giving total maximum score 35 , in which the mean is 26.30 with a standard deviation of 6.628 , the mean percentage 75 . 14.On average, the respondents experience high level of confidence in managing stress due to Work relation. Career development confidence consists of 5 components each having a maximum score of 5 , giving total score 25 , in which the mean is 17.58 with a standard deviation of 4.951 , the mean percentage 70.32. On average, the respondents experience high level of confidence in managing stress due to Career development. Technology changes confidence consist of 5 components each having a maximum score of 5, giving total maximum score 25 , in which the mean is 18.90 with a standard deviation of 5.561 , the mean percentage 75.60. On average, the respondents experience high level of confidence in managing stress due to Technology changes. GenderIssuerelated Stress consist of 2 components each having a maximum score of 5 , giving total maximum score 10 , in which the mean is 7.31 with a standard deviation of 2.604 , the mean percentage 73.10. On average, the respondents experience high level of confidence in managing stress due to Gender Issue. 
associated with various demographical variables. Stress experienced due to technological challenges was significantly related with Age group $\left(\chi^{2}=10.634\right.$, $\mathrm{p}=0.014)$ and Marital status $(\chi 2=5.835, \mathrm{p}=0.016)$.The above table shows how gender issue challenges stress level is associated with various demographical variables. Stress experienced due to gender issue challenges varied significantly at the level of $(p=0.044)$ in the variables Age group $(\chi 2=8.110)$,

Table. No 4.3:Chi-square test results of association between Demographic factors and Confidence Chi-square test results of association between Demographic factors and various Indicators of confidence in handling stress

\begin{tabular}{|c|c|c|c|c|c|c|c|}
\hline \multirow[t]{2}{*}{ Demographics } & \multicolumn{7}{|c|}{ Confidence in Handling stressors } \\
\hline & $\begin{array}{c}\text { Work } \\
\text { family } \\
\text { roles }\end{array}$ & $\begin{array}{c}\text { Work } \\
\text { condition }\end{array}$ & $\begin{array}{c}\text { Work } \\
\text { demand }\end{array}$ & $\begin{array}{l}\text { Working } \\
\text { relation }\end{array}$ & $\begin{array}{c}\text { Career } \\
\text { development }\end{array}$ & $\begin{array}{l}\text { Technological } \\
\text { Challenges }\end{array}$ & $\begin{array}{l}\text { Gender } \\
\text { Issues }\end{array}$ \\
\hline Age Group & $\begin{array}{c}12.627 \\
* *\end{array}$ & $16.148^{*}$ & $3.024^{\mathrm{a}}$ & 5.132 & $21.033^{* *}$ & $17.863 * *$ & 7.479 \\
\hline Marital Status & $\begin{array}{l}44.796 \\
* *\end{array}$ & & & & & $5.983^{*}$ & $4.830^{*}$ \\
\hline $\begin{array}{c}\text { Spouse } \\
\text { employment }\end{array}$ & 7.048 & & & 3.814 & & 6.467 & 1.984 \\
\hline Family Type & .691 & .007 & .756 & .655 & .437 & 2.798 & 1.197 \\
\hline
\end{tabular}

In Table No:4.3 Confidence in dealing with work family conflict varied significantly higher at the level of $(\mathrm{p}=0.00)$ in the variables Age group $\left(\chi^{2}=12.627\right)$ Marital status $(\chi 2=44.796)$. Confidence in dealing with work condition stress varied significantly higher at the level of $(\mathrm{p}=0.00)$ in the variables Age group $\left(\chi^{2}\right.$ $=16.148)$. Confidence in dealing with career development stress varied significantly higher at the level of $(\mathrm{p}=0.00)$ in the variables Age group ( $\chi^{2}$ $=21.003)$ Marital status $(\chi 2=8.777)$. Confidence in dealing with technological challenges varied significantly higher at the level of $(p=0.00)$ in the variables Age group $\left(\chi^{2}=17.863\right)$ and was moderate in Marital status $(\chi 2=5.983)$.Confidence in dealing with gender issue stress varied significantly higher at the level of $(\mathrm{p}=0.00)$ in the variables marital status $\left(\chi^{2}\right.$ $=4.830$ )

\section{Findings}

In descriptive statistics for stress score, on an average respondents experience moderate level of stress due to work family conflict, work condition stress ,work relation stress, carreer development stress ,technological challenges and gender issue .In descriptive statistics for confidence score Confidence in work family conflict, work demand was moderate were as confidence was high in managing work condition stress, work relation stress, career development ,technological challenges and gender issue. When it comes to test results of association between Demographic factors and various stressors and confidence to deal with the same .Married faculties are experiencing high work family conflict stress. Faculties staying in joint family are facing high work family conflict stress $(\mathrm{N}=209)$. Confidence in dealing with work family conflict varied significantly higher at the level of $(\mathrm{p}=0.00)$ in the variables Age group $(\chi 2=12.627)$ Marital status $\left(\chi^{2}=44.796\right)$. Confidence in dealing with work condition stress varied significantly higher at the level of $(\mathrm{p}=0.00)$ in the variables Age group $(\chi 2=16.148)$.. Stress experienced due to career development varied significantly higher at the level of in the variable Spouse employment. Confidence in dealing with career development stress varied significantly higher at the level of in the variables Agegroup Marital status .Stress experienced due to technological challenges was significantly related with Agegroup and Marital status .There was no significant relationship of technological challenges stress with spouse employment and family type . Confidence in dealing with technological challenges varied significantly higher at the level of $(p=0.00)$ in the variables 
Agegroup $(\chi 2=17.863)$. The above table shows how gender issue challenges stress level is associated with various demographical variables. Stress experienced due to gender issue challenges varied significantly at the level of $(\mathrm{p}=0.044)$ in the variables Age $\operatorname{group}\left(\chi^{2}\right.$ $=8.110$ )

\section{Conclusion}

The study identifies that the female faculties working in technical educational institution have high stress .The variable such as work family conflict, working condition, work demand, work relation, career development, technological challenges and gender issue had high level of significance associated with the stress level and the confidence in managing the stress .Further, the result reveals that demographical factor plays a significant role I balancing the stress level and managing it in a confident manner and improving the job performance by adopting coping strategies to manage stress

\section{References}

1. Abouserie, R. (1996). Stress, Coping Strategies and Job Satisfaction in University Academic Staff: An International Journal of Experimental Educational Psychology, 16, pp 49-56.

2. Ackers.(1989). Teachers, Gender and Careers. The Falmer Press, New York. 1989.

3. Aditi, N; and Kumari, B.( 2005). Impact of personality patterns and employment status

On psychological stress tolerance of women in Kerala. Indian Psy.Rev, 64(2), 103- 108.

4. Abrol, K.K., (1990). A study of Language Strain and Coping behaviours of Teachers, Psycholingua, 20:173-178.

5. Albrecht K. (1979). Stress and the Manager: Making it Work for You:NewYork,Simon\& Schuster

6. Aldana SG, Sutton LD, Jacobson BH, Quirk MG., (1996). Relationships between Leisure time physical activity and perceived stress. Department of Physical Education: Brigham Young University, Provo, UT

7. Anita Devi, S.( 2007). Occupational stress: A comparative study of women indifferent occupations: Prajnan, 35(1):61-74.

8. Burke, R. J., \&Richardson, A. M. (1996). Stress, burnout, and health. In C. Cooper (Ed.), Handbook of stress, medicine, and health (pp.101117). Boca Raton, FL: CRC Press.
9. Christopher Gilbers., (2003), "Reviews Evidence Normalizing Breathing Patterns" All India Institute of Medical Science, New Delhi.

10. Charles Kowalski (2002). Caring for Teachers in Uncaring Schools. Curriculum Innovation, Testing and Evaluation: Proceedings of the 1st Annual JALT Pan-SIG

11. Crandall, R. \&Perrewe, L. P., (2005). Occupational Stress: A Handbook. New York: Taylor \& Francis.

12. Dey, E.L., Ramirez, C.E., Korn, W.S., and Astin, A. W. (1993). The American College Teacher: National Norms for the 1992-93 HERI Faculty Survey, Los Angeles: Higher Education Research Institute.

13. Dewe, P. (1986). An investigation into the causes and consequences of teacher stress. New Zealand Journal of Educational Studies, 21 (2), pp 145157.

14. Doune, M. (1999). Teacher Attrition: A Review of Literature. Teaching and Teacher Education, 15, pp 835-848.

15. Drudy,S.(1989). Gender balance/gender bias: the teaching profession and the impact of feminization. Gender and Education. Vol 20, No 4, pp. 309-323.

16. Fried, M. R., (2008). Stress Management for Success in the Workplace: London, Oxford University Press.

17. Gandham, S. R., (2000).The Safety and Health Practioner :Borehamwood, 18(1), 20.

18. Gaurav Bhargava, NeelamSaraswat and Aakanksha Singh (2010). Stress and Stress Management in Recession: Pacific Business Review International, pp 47-58.

19. Geetha Nema, Dhanashree Nagar, YogitaMandhanya (2010). A Study on the Causes of Work Related Stress among the College Teachers, Pacific Business Review International, pp 1-7.

20. Gmelch, W. H. (1993).Coping with Faculty Stress. New York: Sage Publications.

21. Gmelch, W. H. (1984). Educators' responses to stress: Towards a coping taxonomy. Paper presented at the Annual Meeting of the American Educational Research Association: New Orleans, LA.

22. Gmelch, W. H., Lovrich, N. P., and Wilke, P. K., (1984). Stress in Academe: A National Perspective. Research in Higher Education, 20(4), pp 477-490. 
23. Griffith, J., Steptoe, A., and Cropley, M. (1999). An Investigation of Coping Strategies Associated with Job Stress in Teachers: British Journal of Educational Psychology, 69 (4), pp 517-531.

24. Hardie Boys, N. (1996), Workload and Stress: a report of ASTE members. Wellington: New Zealand Council for Educational research and Association of Staff in Tertiary Education.

25. Hardy,Sally(1998),Occupational Stress; Personal and Professional Approaches :United Kingdom,Stanleyhornes Ltd,pp.18-45

26. Haynes, S. G., \&Feinleib, M. (1980). Women, work, and coronary heart disease: Prospective findings from the Framingham Heart Study. American Journal of Public Health, 70, 133141.

27. Hicks, T. \& Caroline, M., (2007). A Guide to Managing Workplace Stress: California Universal Publishers.

28. Hodson R \&ChamerliainL.J.(2003).Sources of reduced Job stress Organizational Coherence, local Ownership and Workers Involvement:Psycholingua,pp.173-178

29. Hui, E. K. P. \& Chan, D. W. (1996). Teacher Stress and Guidance Work in Hong Kong Secondary School Teachers: British Journal of Guidance and Counselling, 24, pp 199-211.

30. Kinnunen; SMauno,S.(1998).Antecedents and outcomes of work-family conflict among employed women and men in Finland. Human Relations: Journal of Occupational Health Psychology Vol51,Pp. 157-177

31. Kinman, G. (2001). Pressure points: A review of research on Stressors and Strains in UK Academics: Educational Psychology, 21, pp 473492.

32. Krohne, H.W. (2001). Stress and Coping Theories: The International Encyclopedia of the Social and Behavioural Sciences:Johannes Gutenberg-University Main Seattle.

33. Kyriacou, C.(1987). Teacher Stress and Burnout: An International Review. Educational Research,53(1).

34. Long, B. C. (2006). Aerobic Conditioning and Stress Inoculation: A Comparison of Stress Management Interventions. Cognitive Therapy and Research, 8, 517-542.

35. Manthei, R. and Solman, R. (1988).Teacher stress and negative outcomes in Canterbury state schools: New Zealand Journal of Educational Studies, 23, pp 145- 163.
36. Monat, A. \& Lazarus, S. R., (2001). Stress and Coping: An Anthology. Columbia: Columbia University Press

37. Mujtaba and McCartney, (2007).Research over the situations begins stress: New Book, Publication,New Delhi. The Icfaian Journal management, Vol VII No-12 Dec 2008

38. Nolan, M. (2009). Top Ten Sources of Workplace Stress and How to Fight Them. Retrieved from people metrics.

39. Naik,S.P.(2008) .Education for the twenty first century. New Delhi: Anmol publications.

40. Olsen, D. (1993). Work Satisfaction and Stress in the first and their year of Academic Appointment. Journal of Higher Education, 64, pp 453-471.

41. Olsen, D. and Maple, S. A. (1993), Gender Differences among Faculty at a Research University: Myths and Realities. Initiatives, 55(4), pp 33-42.

42. Reddy and Poornima, (2012).Role Stress and Coping among Business School Professors:

43. A Phenomenological Study IBS Hyderabad IFHE University, Donthanapalli, Hyderabad, Telangana, India

44. Repetti, R. L., Matthews, K. A., \& Waldron, I. (1989). Employment and women's health: Effects of paid employment on women's mental and physical health. American Psychologist, 44, 13941401.

45. Richard, G.V. and Krieshok, T.S. (1989), Occupational Stress, Strain, and Coping in University Faculty: Journal of Vocational Behaviour, 34, pp 117-132. Sarah Basu (2009), Stress among Teacher Educators:University News, 47(49).

46. Schultz and Schultz (2010),Psychology and work today:Newyork:Prentice Hall.p.374

47. Shonfeld, I. S. (2001), Stress in 1st-year Women Teachers: The Context of Social Support and Coping. Genetic Social and General Psychology Monographs, 127, pp 133-168.

48. Senthil Kumar ,A;Mohan, S; Velmurugan ,R.(2013) Causes of Work Stress of Teachers in Engineering Education: ASIAN JOURNAL OF MANAGEMENT RESEARCH Volume 3 Issue 2, 418

49. Smith, E., Anderson, J.L. and Lovrich, N.P. (1995). The Multiple Sources of Workplace Stress among Land-Grant University Faculty. Research in Higher Education, 36, pp 261-282

50. Smith, E, \& Witt, S. L. (1993). A Comparative Study of Occupational Stress among African 
American and White University Faculty: $A$ Research Note. Research in Higher Education, 34, pp 229-241.

51. Stephen P. Robbins and Timothy A. Judge, (2007), Organizational Behavior:Pearson/Prentice Hall.

52. Sultana, A.M(2013).Constraints faced by Working and Non-working Women in their Families: Australian Journal of Basic and Applied Sciences, Vol7, No 6, Pp. 719-722. 2013.

53. Susan Gill, Marilyn J Davidson., (2001).Organizational Job Satisfaction University of Florida

54. Woods, R. C., \&Montagno, R. V. (1997). Determining the Negative Effect of Teacher Attendance on Student Achievement. Education, 118(2), pp 307-316.

55. Vieet, V. S., (2011). Stress: Coping Mechanisms in the Workplace. Retrieved from $<$ http://voices.yahoo.com/stress-copingmechanisms-workplace

56. Zoe Ann Brown and Denise L. Uehara (1999). Coping with Teacher Stress: A Research Synthesis for Pacific Educators. Pacific Resources of Education and Learning, ED 440 924, pp 1-22. 